\title{
Activity-Dependent Expression of NT-3 in Muscle Cells in Culture: Implications in the Development of Neuromuscular Junctions
}

\author{
Kewei Xie, ${ }^{\text {a }}$ Ti Wang, ${ }^{\text {a }}$ Petur Olafsson, Keiko Mizuno, and Bai Lu \\ Laboratory of Developmental Neurobiology, National Institute of Child Health and Human Development, National Institutes \\ of Health, Bethesda, Maryland 20892-4480
}

\begin{abstract}
Although activity-dependent expression of neurotrophins has been studied extensively in the CNS, its physiological role during synapse development is not well established. At the developing neuromuscular junction in culture, exogenous application of the neurotrophin BDNF or NT-3 has been shown to acutely potentiate synaptic transmission and chronically promote synapse maturation. Using the same cell culture model, we have investigated activity-dependent neurotrophin expression in muscle cells and its role in developing neuromuscular synapses. Membrane depolarization, elicited by either depolarizing agents or repetitive electric stimulation, rapidly and specifically increased the levels of NT-3 mRNA in developing $\mathrm{Xe}-$ nopus laevis muscle cells in culture. NT-3 gene expression also was enhanced by acetylcholine (ACh), the neurotransmitter that causes muscle membrane depolarization. The effects of depolarization were mediated by increasing intracellular calcium concentration. Moreover, factor(s) induced by membrane de-
\end{abstract}

Reciprocal interaction between pre- and postsynaptic cells plays an important role in synapse development. Using the neuromuscular synapse as a model system, we have performed extensive work to identify presynaptic factors that regulate postsynaptic development. For example, acetylcholine receptors (AChR) are induced to cluster at the postsynaptic membrane by agrin, a protein factor derived from presynaptic motoneurons (McMahan, 1990). The transcription of AChR genes in postsynaptic muscle cells is enhanced by ACh receptor-inducing activity (ARIA; Falls et al., 1993; Jo et al., 1995). Postsynaptic muscle cells also provide soluble factors that retrogradely regulate the development of presynaptic motoneurons (Purves and Lichtman, 1985; Oppenheim, 1991; Hall and Sanes, 1993). However, the nature and properties of the postsynaptic factors are much less well understood than the presynaptic factors. Several recent experiments suggest that neurotrophins may be a potential class of postsynaptic factors that regulate the development and function of presynaptic nerve terminals (Lohof et al., 1993; Funakoshi et al., 1995; Stoop and Poo, 1995, 1996; Wang et al., 1995).

Received Dec. 2, 1996; revised Jan. 23, 1997; accepted Feb. 10, 1997.

P.O. is supported by a Swiss National Science Foundation postdoctoral fellowship and a grant from CIBA-Geigy Jubiläums-Stiftung. We thank Drs. Mickey Dugich, Lin Mei, Sidney Udenfriend, and Robert F. Margolskee for helpful discussions and critical comments on this manuscript. We also thank Dr. D. L. Shelton, Genentech, South San Francisco, CA, for the gift of TrkC-IgG fusion protein.

Correspondence should be addressed to Dr. Bai Lu, Unit on Synapse Development and Plasticity, National Institute of Child Health and Human Development National Institutes of Health, Building 49, Room 5A38, 49 Convent Drive, MSC4480, Bethesda, MD 20892-4480.

${ }^{\text {a }}$ These authors contributed equally to this work

Copyright (C) 1997 Society for Neuroscience $0270-6474 / 97 / 172947-12 \$ 05.00 / 0$ polarization appeared to enhance synaptic transmission at the developing neuromuscular junction. The frequency of spontaneous synaptic currents (SSCs) recorded from neuromuscular synapses was increased significantly after treatment with conditioned medium from depolarized muscle cultures. The amplitude, rise time, and decay time of SSCs were not affected, indicating a presynaptic action of the conditioned medium. The effects of the conditioned medium were blocked, partially, by the NT-3 scavenger TrkC-IgG, suggesting that the potentiation of synaptic efficacy was attributable, at least in part, to elevated NT-3 as a consequence of muscle depolarization. Thus, activity-dependent expression of muscle NT-3 may contribute to the development of the neuromuscular synapse.

Key words: neurotrophins; RT-PCR; activity-dependent; membrane depolarization; neuromuscular synapse; nervemuscle co-culture

Neurotrophins are a family of structurally and functionally related proteins that include NGF, BDNF, NT-3, NT-4, and, recently, NT-6 (Korsching, 1993; Gotz et al., 1994). The functions of neurotrophins on distinct neuronal populations are mediated by the cellular expression of the Trk family of tyrosine kinase receptors (Chao, 1992; Barbacid, 1993). TrkA is activated predominantly by NGF, TrkB by BDNF and NT-4, and TrkC by NT-3. At the neuromuscular junction trkB and trkC mRNAs are expressed in motoneurons (Ernfors et al., 1992; Frisen et al., 1992; Funakoshi et al., 1993; Henderson et al., 1993; Koliatsos et al., 1993; Wong et al., 1993; Yan et al., 1993), whereas BDNF, NT-3, and NT-4 are expressed in muscle cells (Schecterson and Bothwell, 1992; Henderson et al., 1993; Koliatsos et al., 1993; Funakoshi et al., 1995). Moreover, BDNF and, to a lesser degree, NT-3 reduce the death of spinal cord motoneurons during development and after axotomy in the adult (Oppenheim et al., 1992; Sendtner et al., 1992; Yan et al., 1992; Henderson et al., 1993; Koliatsos et al., 1993). TrkB knock-out mice exhibit severe deficits in motoneuron function (Klein et al., 1993). These findings imply that neurotrophins serve as muscle-derived target factors that promote motoneuron survival.

Despite rapid advances in neurotrophin research, functional studies have concentrated primarily on the roles of neurotrophins in neuronal survival and differentiation (Barde, 1989; Thoenen, 1991). However, the fact that expression of neurotrophins in the CNS is rapidly enhanced by neuronal activity (Gall and Isackson, 1989; Zafra et al., 1990, 1991; Ernfors et al., 1991; Isackson et al., 1991; Lu et al., 1991; Thoenen, 1991; Castren et al., 1992, 1993; Patterson et al., 1992) suggests that they also have a role in 
activity-dependent processes, such as synaptic development and plasticity (Lo, 1995; Thoenen, 1995). This idea was supported further by several recent experiments. Neurotrophins rapidly regulate neuronal activity and synaptic transmission in brain neurons in culture (Kim et al., 1994; Knipper et al., 1994; Lessmann et al., 1994; Levine et al., 1995) and in hippocampal slices (Kang and Schuman, 1995). The neurotrophin BDNF enhances synaptic responses to high-frequency stimulation and promotes long-term potentiation (LTP) in developing hippocampus (Figurov et al., 1996). These results are consistent with the finding that LTP is impaired in adult BDNF knock-out mice (Korte et al., 1995; Patterson et al., 1996). Moreover, neurotrophins have been shown to play a role in the development of ocular dominance columns in the visual cortex (Domenici et al., 1991; Maffei et al., 1992; Cabelli et al., 1995).

The neuromuscular junction is one of the best systems to study synaptic function of neurotrophins. In Xenopus laevis nerve-muscle co-culture, acute exposure to BDNF or NT-3 rapidly increases the frequency of spontaneous synaptic currents (SSCs) and the amplitude of impulse-evoked synaptic currents (ESCs; Lohof et al., 1993). The neurotrophin effect seems to be mediated by an increase in $\mathrm{Ca}^{2+}$ concentration at presynaptic terminals, leading to enhanced transmitter release (Stoop and Poo, 1995, 1996). In a different set of experiments, chronic treatment of the nervemuscle culture with neurotrophins promotes the maturation of the neuromuscular junction (Wang et al., 1995). Thus, the spontaneous and evoked synaptic currents recorded at the neuromuscular synapses exhibit more mature properties. There is a significant enhancement of the expression of synaptic vesicle proteins, such as synaptophysin and synapsin I. The number of varicosities also increased after neurotrophin treatment. Interestingly, NT-3 seems to have more potent effects than BDNF. A number of important questions remain to be addressed. Are neurotrophins expressed in muscle cells during neuromuscular development? Is the expression of neurotrophins in muscle cells activitydependent? Can muscle-derived neurotrophins serve as retrograde messages at the neuromuscular synapse? Our studies provide direct evidence for the activity-dependent regulation of NT-3 expression in embryonic muscle cells and suggest that NT-3 mediates the activity-dependent potentiation of the neuromuscular synapse during development.

\section{MATERIALS AND METHODS}

Culture preparation. Xenopus muscle cultures were prepared by the published procedure with minor modification (Tabti and Poo, 1991; Lu et al., 1992). The dorsal part of Xenopus 1-d-old embryos (stage 20-22; Nieuwkoop and Faber, 1967) was dissected and incubated in a collagenase solution $(0.5 \mathrm{mg} / \mathrm{ml}$ in Ringer's solution, type IV; Sigma, St. Louis, MO) for 30-50 min. The neural tubes were removed, and the remaining myotomal tissues were digested in $\mathrm{Ca}^{2+}-\mathrm{Mg}^{2+}$-free saline supplemented with EDTA (CMF: $58.2 \mathrm{~mm} \mathrm{NaCl}, 0.7 \mathrm{~mm} \mathrm{KCl}$, and $0.3 \mathrm{~mm}$ EDTA, pH 7.4) for 15-20 min. Cells derived from four to six embryos were dissociated, plated on a plastic dish, and grown in culture medium at room temperature $\left(20-22^{\circ} \mathrm{C}\right)$ for $1-7 \mathrm{~d}$ before being used for experiments. The development of muscle cells in culture is very similar to that seen during various time points of Xenopus development in vivo (Kullberg et al., 1977; Cohen, 1980; Bridgman et al., 1984; Peng et al., 1991). The cultured muscle cells were not undifferentiated myoblasts, because they did not undergo mitosis any more. There were some morphological changes in culture. They were initially (after $1 \mathrm{~d}$ in culture) round "myoballs" with single nuclei. Later they turned into single-nucleus spindle-shaped cells. After 2-3 d some of them fused to become myotubes with a few nuclei. In most cases the embryonic muscle cells were cultured for $3 \mathrm{~d}$. The culture medium consisted (v/v) of 3\% fetal calf serum (FCS; Life Technologies, Gaithersburg, MD), 50\% Leibovitz L-15 medium (Sigma), and $47 \%$ Ringer's solution containing (in $\mathrm{mM}$ ): $115 \mathrm{NaCl}, 2 \mathrm{CaCl}_{2}, 2.5 \mathrm{KCl}$, and 10 HEPES, pH 7.6. We later omitted the collagenase digestion step, because the old cultures ( $3 \mathrm{~d}$ or older) contained very few neurons and no other cell types and RT-PCR experiments indicated that there was no difference in neurotrophin gene expression with either method. On the day of the experiments the drugs were added directly to culture media at the desired concentrations and incubated for the desired lengths of time. Then the media were removed. The cultures were rinsed with Ringer's solution and harvested for RNA extraction.

The 1-d-old nerve-muscle cultures used in electrophysiological experiments were prepared essentially as described (Tabti and Poo, 1991; Lu et al., 1992). Briefly, the neural tube and the associated myotomal tissue of stage 20-22 Xenopus embryos were dissociated in CMF, and the dissociated cells from one embryo were plated on a glass coverslip and grown at room temperature for $1 \mathrm{~d}$ before use. The culture medium contained (v/v) $1 \%$ FCS, $50 \%$ L-15, and $49 \%$ Ringer's solution. The same lot of FCS, which had no neurotrophin activity (on neurite growth, synaptic vesicle protein expression, etc.) was used in all experiments. A majority of neurons in the Xenopus nerve-muscle co-culture are cholinergic neurons (see Sun and Poo, 1987), which form functional synapses with myocytes in culture very shortly after nerve-muscle contact (Kidokoro and Yeh, 1982; Xie and Poo, 1986), similar to what has been observed in vivo (Cohen, 1980, 1987; Myers et al., 1986; Westerfield et al., 1986; Peng et al., 1989, 1991).

Physiological stimulation of cultured muscle cells. For electric stimulation the muscle cultures were stimulated indirectly via two agarose bridges (1\% agarose in Ringer's solution). Agarose bridges were used to stimulate the muscle cells without direct contact of culture media with the silver electrodes, which may be electrolyzed to create $\mathrm{HCl}$ gas. The electric stimulus was delivered at $6 \mathrm{~Hz}$ for $1 \mathrm{hr}$ with a voltage that was just above the threshold of muscle contraction. The polarity of the electrodes was switched in 10-15 min intervals. The contraction of the muscle cells was monitored constantly under the microscope during the course of the stimulation.

To minimize the desensitization of nicotinic receptors induced by ACh or carbachol treatment, we perfused the cholinergic agonists into the cultures for $5 \mathrm{~min}$, followed by a $10 \mathrm{~min}$ wash with Ringer's solution. This procedure was repeated eight times, and the total experiment lasted for $2 \mathrm{hr}$.

Cloning of Xenopus NT-3. Initially, we used RT-PCR (see below) on RNA from adult Xenopus muscle with the specific primers XNT-1 (Xenopus; Hallbook et al., 1991) and CNT-2 (chicken; Maisonpierre et al., 1992) to obtain the 146 bp PCR fragment XNT-1/2, which includes the 66 bp published Xenopus NT-3 sequence. Rapid amplification of cDNA ends (RACE)-PCR (McGinnis et al., 1992) with specific Xenopus primers led to a $462 \mathrm{bp}$ fragment, not long enough to cover the whole coding sequence. PCR with specific primer sets HNT 3/XNT 4 and XNT 5/HNT 6 designed from the RACE-PCR product and the conserved human sequence (Jones and Reichardt, 1990) led to two overlapping PCR fragments, 551 and $486 \mathrm{bp}$ in length. These PCR products were reamplified, kinased, and cloned into M13mp19 for sequencing. Specific primers used for cloning are listed as follows:

XNT 1: 5'-GAATTCCAGTGTTTGTCG-3'

CNT 2: 5'-GACATTAGAGGACACCAGGT-3'

HNT 3: 5'-ATGTCCATCTTGTTTTATGTG-3'

XNT 4: 5'-GTTTTAATTTCCCCCAACAC-3'

XNT 5: 5'-TAATGGATGATTATATTG-3'

HNT 6: 5'-CATTTATATGCTACATGC-3'

$R T-P C R$ assay. Upon treatment with various drugs, the cultured Xenopus muscle cells were rinsed briefly with Ringer's solution. Total RNA was extracted from cultured Xenopus muscle cells by the RNAzol method (Biotecx Laboratories, Houston, TX). RT-PCR was performed with a modification of standard protocol (Frohman, 1990; Rao, 1994). Briefly, total RNA from one dish of muscle cells was reverse-transcribed with oligo-dT $_{16}$ primers (Pharmacia, Piscataway, NJ), and $\sim 0.1 \mu \mathrm{g}$ of cDNA was generated. The reverse-transcribed cDNA then was used in the PCR $\left(1 \mathrm{~min} / 95^{\circ} \mathrm{C}, 1 \mathrm{~min} / 55^{\circ} \mathrm{C}, 1 \mathrm{~min} / 72^{\circ} \mathrm{C}\right.$; for $25-35$ cycles $)$ to measure neurotrophin gene expression. According to the published sequences of Xenopus NGF, BDNF, NT-4 (Hallbook et al., 1991), and the sequence for NT-3 derived by our experiments, the predicted sizes for the respective neurotrophins are NGF, 522 bp; BDNF, 377 bp; NT-3, 402 bp; and NT-4, 548 bp. $\alpha{ }^{3}{ }^{3} \mathrm{P}-\mathrm{dATP}$ was used to label the reaction products. The radioactive PCR products were separated on $6 \%$ nondenaturing PAGE. The gel was dried, and the intensity of the PCR products was quantified by phosphoimaging. Specific primers used in the RT-PCR assay are listed as follows: 
ATGICCATCTIGITITATGIGATGTTCTTCCATATCTTTGTGGCATCCACGCTACCAAC

60

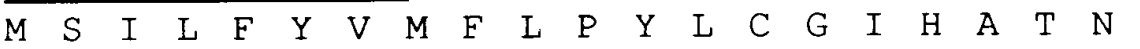

ATGGATAAAAGGAATTTGOCAGAAAACTCGATGAATTCTCTGTTTATCAAACTTATTCAA

120

$\begin{array}{llllllllllllllllllllllllllll}M & D & K & R & N & L & P & E & N & S & M & N & S & L & F & I & K & L & I & Q\end{array}$

GCAGAOCTTTTGAAAAACAAGATTTOCAAGCAGACGGTTGATACCAAAGAAAACCATCAA

180

$\begin{array}{llllllllllllllllllll}A & D & I & L & K & N & K & I & S & K & Q & T & V & D & T & K & E & N & H & Q\end{array}$

AGCACCATACCAAAGCCACAAATTCTTCTTGACTIGGATGGGGATGATAATATGAAACAA

240

$\begin{array}{llllllllllllllllllll}S & \mathrm{~T} & \mathrm{I} & \mathrm{P} & \mathrm{K} & \mathrm{P} & \mathrm{Q} & \mathrm{I} & \mathrm{L} & \mathrm{L} & \mathrm{D} & \mathrm{L} & \mathrm{D} & \mathrm{G} & \mathrm{D} & \mathrm{D} & \mathrm{N} & \mathrm{M} & \mathrm{K} & \mathrm{Q}\end{array}$

GACTTCCAA CAGTCATCTCATTAGAAG AGAACTGGTAAAACAGCAGAAGCAACGGCGA

300

$\begin{array}{llllllllllllllllllll}D & F & Q & P & V & I & S & L & E & A & E & L & V & K & Q & Q & K & Q & R & R\end{array}$

TACAAATCACCTAGGGTACITTTGAGTGATAGCCTTCCTTTGGAACCTCCTCCCTTGTAC

360

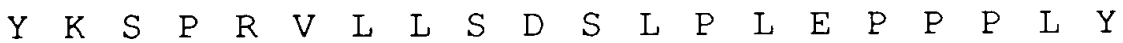

CIAATGGATGATTATATTGGGCATTCAACGGIGGTAAATAACAGAACCTCAAGGAGAAAA

420

$\begin{array}{llllllllllllllllllll}L & M & D & D & Y & I & G & H & S & T & V & V & N & N & R & T & S & R & R & K\end{array}$

AGATTTGCAGAGCATAAAGGCCATAGAGGGGATATTCAGTTTGTGACAGTGAAAGITTG

480

$\begin{array}{llllllllllllllllllll}R & F & A & E & H & K & G & H & R & G & E & Y & S & V & C & D & S & E & S & L\end{array}$

TGGGTTACAGACAAAATGAATGCAATTGACATTCGAGGACACCAAGIAACTGIGITGGGG

$\begin{array}{lllllllllllllllllllll}W & V & T & D & K & M & N & A & I & D & I & R & G & H & Q & V & T & V & L & G\end{array}$

GAAATTAAAACAGGAAATTCTCCTGIGAAACAATACTTTTATGAAACAAGGIGTAAAGAG

600

\begin{tabular}{lllllllllllllllllllllllllll}
\hline & $I$ & $K$ & $T$ & $G$ & $N$ & $S$ & $P$ & $V$ & $K$ & $Q$ & $Y$ & $F$ & $Y$ & $E$ & $T$ & $R$ & $C$ & $K$ & $E$
\end{tabular}

GCAAGACCTGTCAAAAATGGCTGTCGTGGCATAGAEGACAAACACTGGAATTCLCAATGT

$\begin{array}{lllllllllllllllllllllllllll}A & R & P & V & K & N & G & C & R & G & I & D & D & K & H & W & N & S & Q & C\end{array}$

AAAACCTCACAAACTTACGTGAGAGCATTGACTTCAGAAAATAACAAAATGGTGGGTTGG

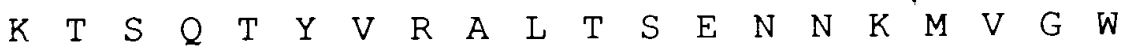

CGGIGGATAAGAATAGACACATCCTGOGITTGTGCATTATCAAGGAAAATOGGAAGATCA

$\begin{array}{llllllllllllllllllll}R & W & I & R & I & D & T & S & C & V & C & A & L & S & R & K & I & G & R & S\end{array}$

TAACTGCATTGITTTTACATATAAATTATTCCTTTAAATTATATGATATGCATGIAGCAT

840

ATAAATG

847

Figure 1. Nucleotide and amino acid sequence of Xenopus NT-3. The deduced amino acid sequence, in single-letter code, is shown below the nucleotide sequence. Primers used for cloning are underlined (in the order of appearance: HNT 3, XNT 5, XNT 4, and HNT 6). Primers used for the quantitative RT-PCR assay are boxed (NT-3-1 and NT-3-2).

NGF-1: 5'-CCGCATTCCTCATCACACAC-3' NGF-2: 5'-CCTCCCTTCCATTGTTAATGC-3' BDNF-1: 5'-ACTCTGACCCAGCCAGGCGT-3' BDNF-2: 5'-CAGTGTACATACACAAGAAG-3'

NT-3-1: 5'-GAATTCCAGTGTTTGTCG-3'

NT-3-2: 5'-CAGTCATCTCATTAGAAGC-3'

NT-4-1: 5'-GTGATCTCATACTGTTGTGC-3'

NT-4-2: 5'-TGCTTTTTGTCTACACCTCG-3'

EF-1: 5'-CAAATGCAGGGACCCAAAGCTAGTTTCAAG-3'

EF-2: 5'-CGTAATTGTTACCTTCCCTTCGTTCGTCGT-3'
EF-1 and EF-2 represent primers for elongation factor $1 \alpha(\mathrm{EF}-1 \alpha)$. To ensure that the phosphoimaging signals faithfully reflect the changes in neurotrophin mRNA levels in muscle cells under different experimental conditions, we took the following measures. (1) The linear range of PCR cycle numbers for each individual gene was determined experimentally, and the cycle number near the midpoint of the linear range was used: EF- $1 \alpha$, 26 cycles; NGF, 35 cycles; BDNF, 31 cycles; NT-3, 33 cycles. (2) To compensate for variability of input of the first strand cDNA in each assay, we normalized the signal for each neurotrophin gene against EF- $1 \alpha$, which is expressed ubiquitously and constitutively and does not 


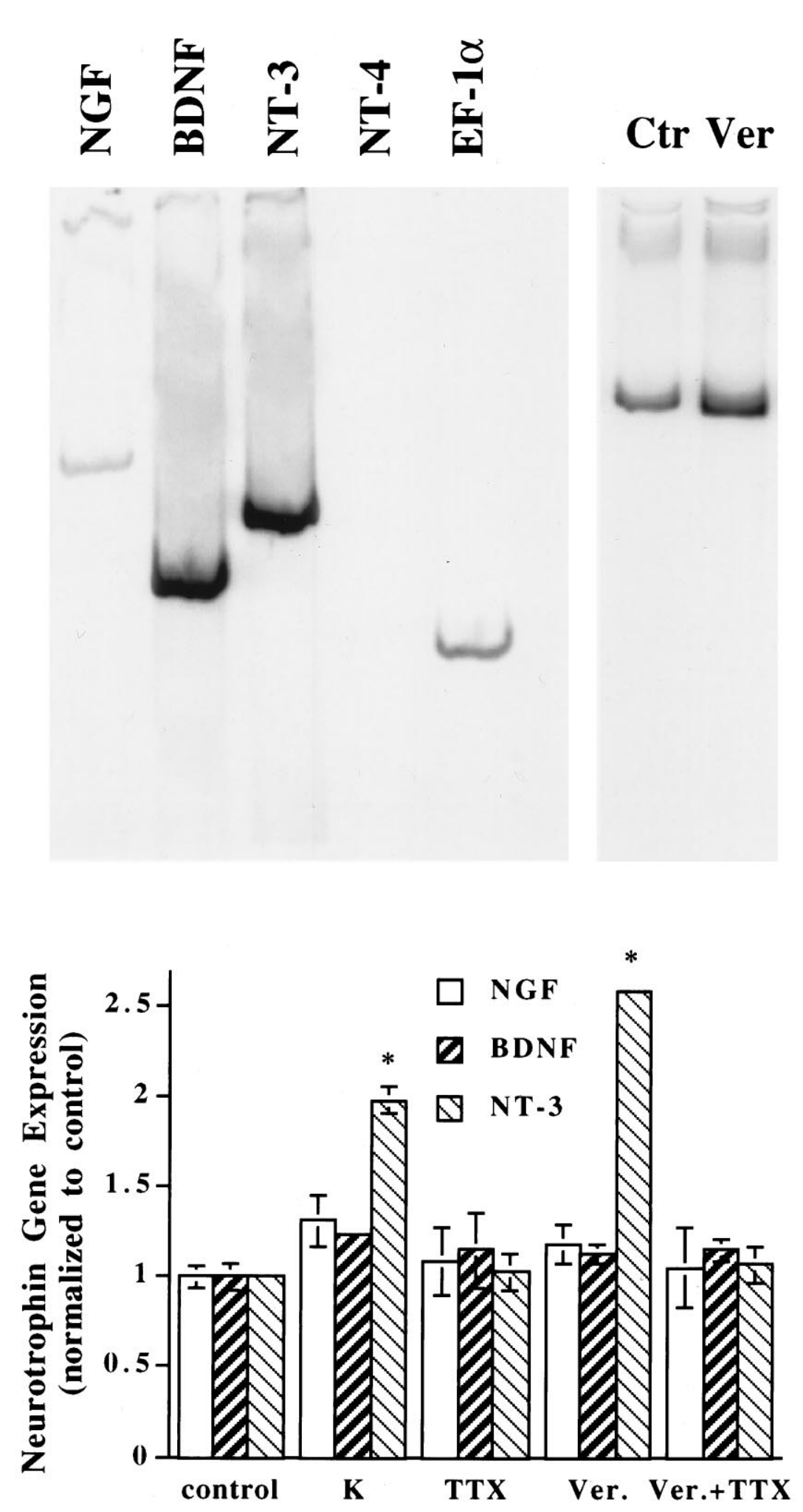

Figure 2. Effect of membrane depolarization on neurotrophin gene expression in Xenopus embryonic myocytes cultured for $3 \mathrm{~d}$. Top, Left, A representative gel showing the expression of neurotrophin genes in these cells. The PCR products (cycle numbers: $E F-1 \alpha, 24$; all neurotrophins, 34 ) were separated on a $6 \%$ acrylamide gel and viewed by phosphoimaging. The PCR products exhibited predicted sizes for the respective neurotrophins $(N G F, 522 \mathrm{bp} ; B D N F$, $377 \mathrm{bp} ; N T-3,402 \mathrm{bp}$ ). Although NT-4 was not detectable in this experiment with the use of embryonic muscle cells, similar PCR that used mRNA from adult leg muscle exhibited the predicted 548 bp band. Top, Right, A representative gel showing the effect of depolarization on muscle NT-3 mRNA expression. Myocytes were cultured for $3 \mathrm{~d}$ and treated with $(\mathrm{Ver})$ or without $(\mathrm{Ctr})$ veratridine $(10 \mu \mathrm{M})$ for 2 hr. RNA was extracted from each of these cultures and processed for RT-PCR assay. Note that the signals for NT-3 were normalized to that for EF- $1 \alpha$. Bottom, Summary of the effect of membrane depolarization on neurotrophin gene expression in embryonic myocytes. Six such experiments were performed, and all generated similar results. This figure shows results from one such experiment. Xenopus muscle cells from stage 22 embryos were cultured for $3 \mathrm{~d}$ and then treated with the indicated drugs for $1 \mathrm{hr} . K, \mathrm{KCl}, 35$ $\mathrm{mm}$; TTX, tetrodotoxin, $1 \mu \mathrm{M} ; \mathrm{Ver}$, veratridine, $10 \mu \mathrm{M}$; control, no drug treatment. Each group contains cultures in triplicate. RNA was extracted from each of these cultures and processed for RT-PCR assay. The signal of neurotrophin mRNA from each of these cultures was normalized to that of EF- $1 \alpha$ mRNA from the same culture. The signals for each condition were averaged. Then the relative levels of neurotrophin mRNAs were obtained by normalizing data from all experimental conditions to control values. In this and all other figures, error bars are SD. *Significantly different from control ( $p<0.001$, two-tailed Student's $t$ test).

change under various experimental conditions. (3) The linearity of the assay was determined by varying the amount of input cDNA in the PCR. The amount of input cDNA that falls in the middle of the linear range was used. (4) Within each assay triplicates or quadruplicates of cDNA were used in the PCR, and the mean \pm SD is presented in the figures. Assays under the same experimental conditions were repeated at least three times, and the number of experiments is given in the text and figures.

Preparation of conditioned medium. Xenopus muscle cultures (3-d-old) were rinsed with Ringer's solution, followed by veratridine treatment (10 $\mu \mathrm{M}$ ) for $3 \mathrm{hr}$. The supernatant of the cultures (the conditioned medium, $\mathrm{CM}$ ) was combined and dialyzed by centrifugation in a Centricon-10 tube (molecular cutoff $10 \mathrm{kDa}$; Amicon, Beverly, MA) at $7500 \times g$ for $2 \mathrm{hr}$ to remove veratridine, resuspended in $2 \mathrm{ml}$, and centrifuged again for $2 \mathrm{hr}$. The final volume of CM from one culture was $\sim 100 \mu \mathrm{l}$.

Electrophysiology. SSCs were recorded from innervated muscle cells by 

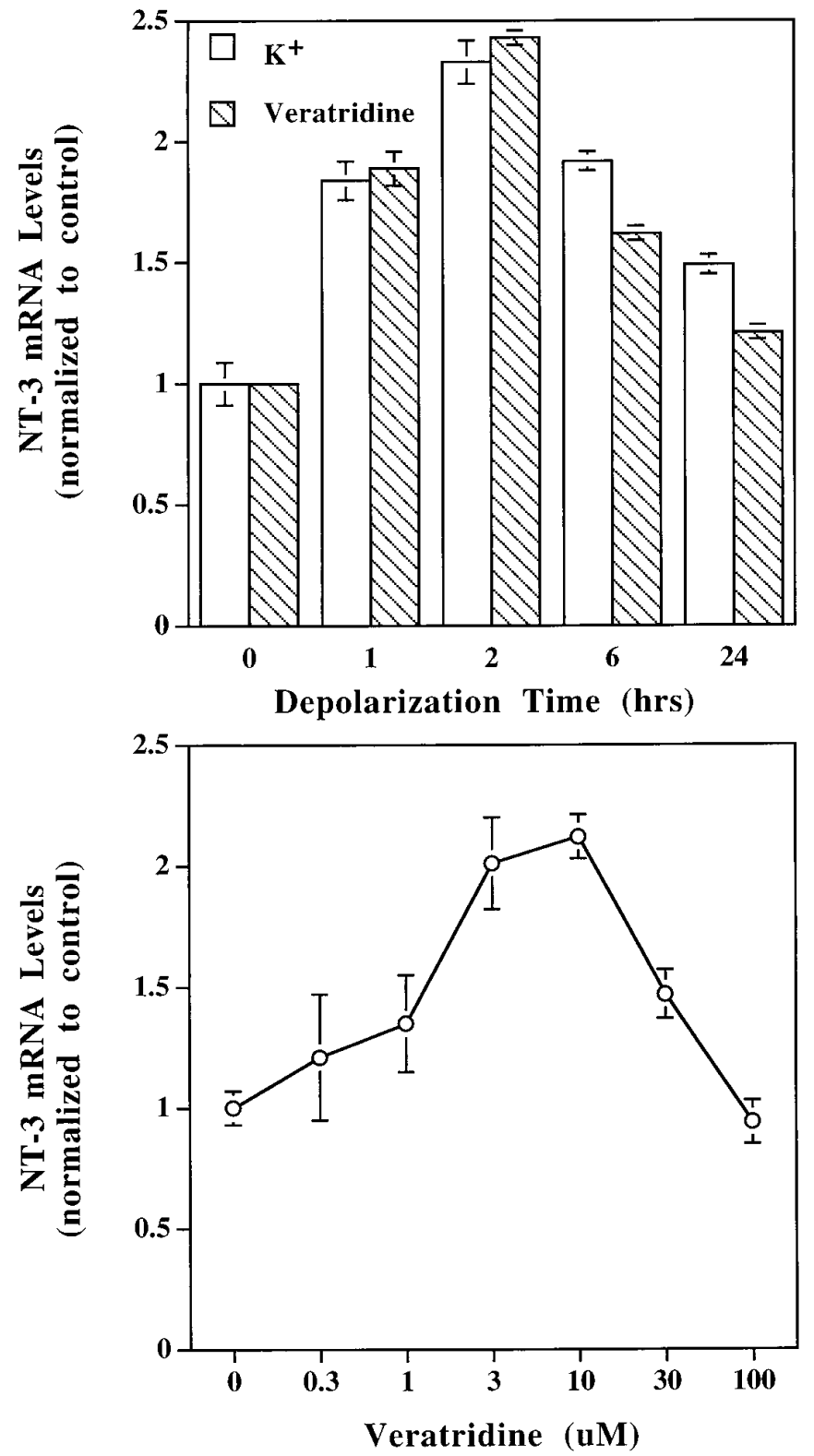

Figure 3. Characterization of depolarization-induced NT-3 gene expression. Embryonic Xenopus muscle cells were cultured for $3 \mathrm{~d}$ and then treated with the depolarizing agents veratridine or $\mathrm{K}^{+}$and harvested for NT-3 mRNA measurement with RT-PCR assay, as described in Figure 2. Top, Time course of NT-3 gene expression induced by depolarization. $\mathrm{KCl}$ $(35 \mathrm{~mm})$ or veratridine $(10 \mu \mathrm{M})$ was applied to the cultures at time 0 (control). The muscle cells were harvested at different time points after depolarization. The experiments were performed three times $(n=3)$, and the results were virtually identical. A typical result is shown. Bottom, Concentration dependence of veratridine effects. The muscle cultures were treated for $2 \mathrm{hr}$ with different concentrations of veratridine, as indicated. Control, no veratridine treatment; $n=3$.

whole-cell recording methods (Hamill et al., 1981; Lu et al., 1992) at room temperature in culture medium. The solution inside the whole-cell recording pipette contained (in $\mathrm{mM}$ ): $150 \mathrm{KCl}, 1 \mathrm{NaCl}, 1 \mathrm{MgCl}_{2}$, and 10 HEPES buffer, $\mathrm{pH}$ 7.2. All data were collected by a patch-clamp amplifier (EPC-7), with a current signal filter at $3 \mathrm{kHz}$. The data were stored on a videotape recorder for later playback on a storage oscilloscope (Textronic TDS 420) and a chart recorder (Gould EasyGraf 240, Glen Burnie, MD) and for analysis by the SCAN program (Dagan, Minneapolis, MN). Conditioned medium was applied directly to the nerve-muscle cultures after a period of control recording. Considering the loss of factors during
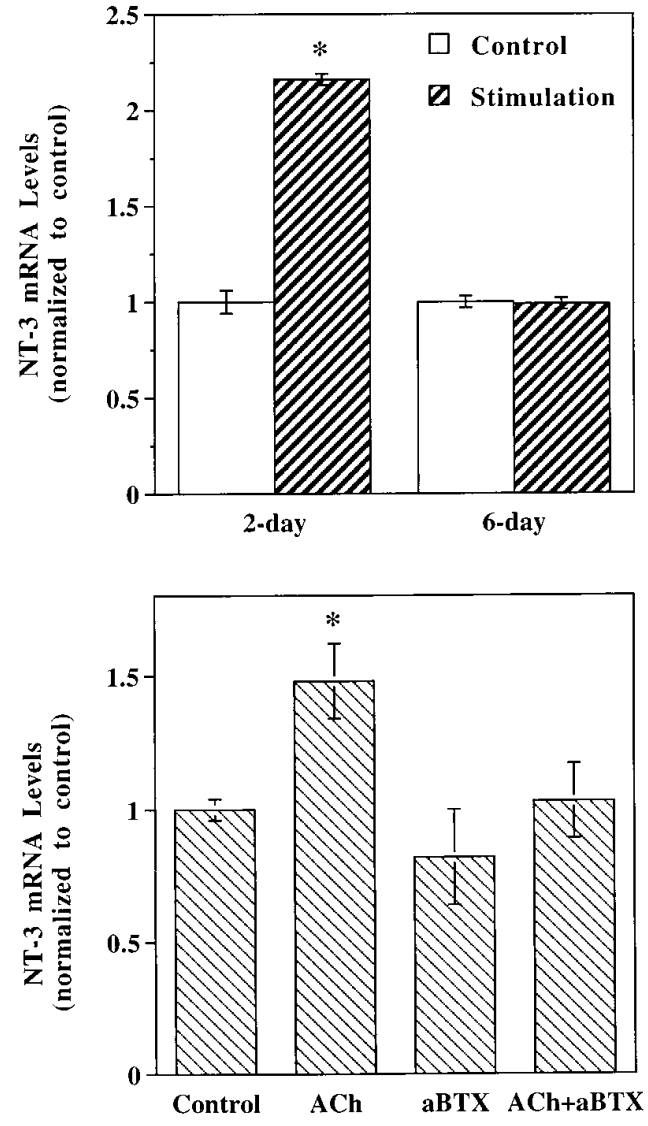

Figure 4. Effects of electric stimulation and ACh on the levels of muscle NT-3 mRNA. Top, Effects of electrical stimulation. Xenopus muscle cultures of different developmental stages (2-day and 6-day) were stimulated at $6 \mathrm{~Hz}$ via agarose bridges for $1 \mathrm{hr}$. Stimulation intensity was adjusted to be just above the threshold of muscle contraction. Control, No electrical stimulation; $n=3$. Bottom, Effects of ACh. Muscle cells cultured for $3 \mathrm{~d}$ were treated with $A C h(0.1 \mathrm{~mm}), \alpha$-bungarotoxin $(a B T X, 10 \mu \mathrm{g} / \mathrm{ml})$, or both, as indicated. Drugs and Ringer's solution were perfused to muscle cultures alternately $(5 \mathrm{~min} / 10 \mathrm{~min})$ for a total of $2 \mathrm{hr}$. Control, No drug treatment; $n=3$.

Centricon preparation, the amount of $\mathrm{CM}$ applied to a nerve-muscle culture was $\sim 200 \mu$ l, which was equivalent of the supernatant from two dishes. For TrkC-IgG blocking experiments, the cultures were treated with TrkC-IgG $(1 \mu \mathrm{g} / \mathrm{ml})$ for $0.5-2 \mathrm{hr}$ before recording. A minimum of 50 SSC events recorded from the same cell before and 5-10 min after application of CM were analyzed.

\section{RESULTS}

\section{RT-PCR assay for neurotrophin gene expression}

Because of the limited number of cells in the Xenopus muscle cultures (no more than 10,000 myocytes), conventional RNA detection methods such as Northern blot or RNase protection cannot be used to measure neurotrophin mRNAs. A sensitive and quantitative RT-PCR assay was needed to quantify neurotrophin gene expression (Frohman, 1990; Rao, 1994). Preliminary experiments indicated that the known 66 bp Xenopus NT-3 sequence (Hallbook et al., 1991) was insufficient for reliable quantitative RT-PCR. Using PCR, RACE, and specific primers corresponding to conserved sequences of chicken (Maisonpierre et al., 1992), mouse (Hohn et al., 1990), rat (Maisonpierre et al., 1990), and human (Jones and Reichardt, 1990) NT-3 genes, we cloned a cDNA encoding full-length Xenopus NT-3 protein (Fig. 1). Xenopus NT-3 showed $77-78 \%$ identity in the full-length 260 amino 


\begin{tabular}{|c|c|c|c|c|}
\hline \multicolumn{5}{|c|}{$\mathrm{Ca}^{2+}$ ionophores } \\
\hline Control & A23187 $3 \mu \mathrm{M}$ & Ionomycin $3 \mu \mathrm{M}$ & & \\
\hline $1.00 \pm 0.03$ & $1.64 \pm 0.03^{*}$ & $1.81 \pm 0.01^{*}$ & & \\
\hline \multicolumn{5}{|c|}{$\mathrm{Ca}^{2+}$-free media } \\
\hline Control & $\mathrm{K}^{+} 35 \mathrm{mM}$ & Control & Veratridine $10 \mu \mathrm{M}$ & \\
\hline $1.00 \pm 0.02$ & $0.97 \pm 0.10$ & $1.00 \pm 0.05$ & $0.67 \pm 0.13$ & \\
\hline \multicolumn{5}{|l|}{$\mathrm{Cd}^{2+}$ media } \\
\hline Control & $\mathrm{K}^{+} 35 \mathrm{mM}$ & Control & Veratridine $10 \mu \mathrm{M}$ & \\
\hline $1.00 \pm 0.07$ & $0.96 \pm 0.03$ & $1.00 \pm 0.07$ & $0.84 \pm 0.09$ & \\
\hline \multicolumn{5}{|l|}{ L-type channels } \\
\hline Control & Veratridine $10 \mu \mathrm{M}$ & $\begin{array}{l}\text { Veratridine } 10 \mu \mathrm{M} \\
\quad+\text { nitrendipine } 10 \mu \mathrm{M}\end{array}$ & $\begin{array}{l}\text { Veratridine } 10 \mu \mathrm{M} \\
\quad+\text { nifedipine } 10 \mu \mathrm{M}\end{array}$ & $\begin{array}{l}\text { Veratridine } 10 \mu \mathrm{M} \\
\quad+\text { verapamil } 10 \mu \mathrm{M}\end{array}$ \\
\hline $1.00 \pm 0.02$ & $2.69 \pm 0.08^{*}$ & $2.31 \pm 0.21^{*}$ & $1.84 \pm 0.13^{*}$ & $1.65 \pm 0.12^{*}$ \\
\hline
\end{tabular}

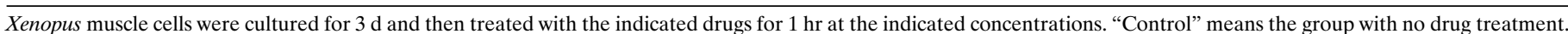

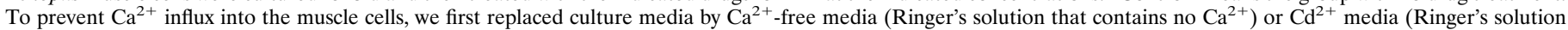

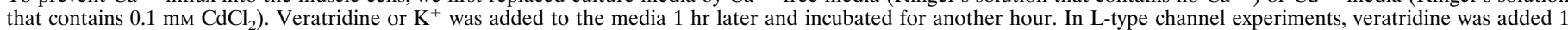

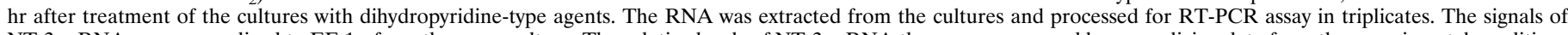

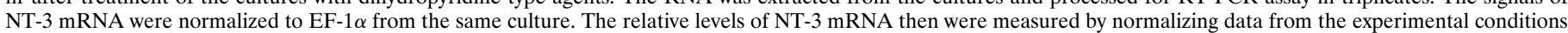

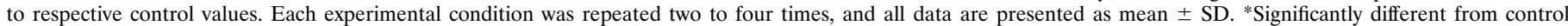
$(p<0.01$, two-tailed Student's $t$ test $)$.

acid sequences, whereas the mature NT-3 protein had $94-95 \%$ identity to the four known NT-3s from the above species (data not shown). Xenopus NT-3 sequence information was used to design primers for NT-3 RT-PCR assay.

The exogenous neurotrophins BDNF and NT-3 have been shown to enhance transmitter release (Lohof et al., 1993) and to facilitate synaptic maturation (Wang et al., 1995) at the developing neuromuscular junction in Xenopus nerve-muscle cultures. To determine whether endogenous neurotrophins are expressed in developing Xenopus myocytes, we reverse-transcribed total RNA harvested from muscle cells cultured for $3 \mathrm{~d}$ ( $3 \mathrm{~d}$ muscle cultures), and we used primers corresponding to sequences of specific neurotrophins for PCR reactions. The PCR products of the respective neurotrophins exhibited predicted sizes (Fig. 2, top, left). Sequence analysis of the PCR products confirmed the identities of the neurotrophins (data not shown). Different levels of NGF, BDNF, and NT-3 mRNAs were detected (Fig. 2, top, left, $n=4$ ). In the $3 \mathrm{~d}$ muscle cultures, there was virtually no NT-4 mRNA (Fig. 2, top, left), although the message was detected in later stages of development (data not shown).

\section{Effects of membrane depolarization on neurotrophin gene expression}

The role of membrane depolarization on neurotrophin gene expression was examined by the application of commonly used depolarizing agents, such as $\mathrm{K}^{+}$(high concentrations, e.g., $35 \mathrm{~mm}$ ) or veratridine $(10 \mu \mathrm{M})$, to muscle cells after they were cultured for $3 \mathrm{~d}$. An example of the veratridine effect on the level of muscle NT-3 mRNA is shown in Figure 2 (top, right). To ensure that the RT-PCR assay was linear and semiquantitative, we took a number of circumspect measures (see Materials and Methods). Particularly, triplicated or quadruplicated signals for each neurotrophin gene were normalized against constitutively expressed EF- $1 \alpha$ in the respective group, and assays under the same experimental conditions were repeated a few times. Exposure of the $3 \mathrm{~d}$ muscle cultures to elevated $\mathrm{K}^{+}$for $1 \mathrm{hr}$ resulted in a specific increase in the levels of NT-3 mRNA without affecting the expression of other neurotrophin genes (Fig. 2, bottom, $n=6$ ). Treatment of the cultures with veratridine $(10 \mu \mathrm{M}), \mathrm{a} \mathrm{Na}^{+}$channel agonist, elicited a 2.5-fold increase in NT-3 mRNA expression. The effects of veratridine were blocked by tetrodotoxin (TTX, $1 \mu \mathrm{M}$ ), $\mathrm{a} \mathrm{Na}^{+}$ channel antagonist, indicating that the veratridine effect indeed was mediated by voltage-dependent $\mathrm{Na}^{+}$channels (Fig. 2, bottom).

The expression of the NT-3 gene in muscle cells cultured for $3 \mathrm{~d}$ was studied in further detail with the RT-PCR assay. NT-3 gene expression was increased very rapidly after membrane depolarization. The levels of NT-3 mRNA peaked $\sim 2 \mathrm{hr}$ after $\mathrm{K}^{+}$or veratridine treatments (Fig. 3, top, $n=3$ ), and the effects subsided after prolonged depolarization. The effects of both $\mathrm{K}^{+}$and veratridine were dose-dependent. Maximal stimulation of NT-3 gene expression was achieved by $50 \mathrm{~mm} \mathrm{~K} \mathrm{~K}^{+}$. The optimal concentration for the veratridine effects was 3-10 $\mu \mathrm{M}$ (Fig. 3, bottom, $n=3$ ).

\section{Effects of electric stimulation and ACh on the levels of muscle NT-3 mRNA}

To mimic muscle depolarization under physiological conditions, we stimulated the muscle cultures repetitively for $1 \mathrm{hr}$ via two agarose bridges. Stimulation intensity was adjusted to a level just above the threshold of muscle contraction. Repetitive stimulation specifically increased the levels of NT-3 mRNA in muscle cells cultured for $2 \mathrm{~d}$ (Fig. 4, top, $n=3$ ) and $3 \mathrm{~d}$ (data not shown). However, electric stimulation did not affect NT-3 gene expression in muscle cells cultured for $6 \mathrm{~d}$ (Fig. 4) and $7 \mathrm{~d}$ (data not shown), suggesting that the effects of depolarization depend on the developmental stages of the muscle cells.

Muscle contraction in vivo normally is induced by $\mathrm{ACh}$, the neurotransmitter released from motor nerve terminals. To determine whether activation of nicotinic ACh receptors is involved in neurotrophin gene expression in muscle, we treated the myocytes with the nicotinic agonists ACh or carbachol after $3 \mathrm{~d}$ in culture. The cultured muscle cells were exposed alternately with ACh or carbachol (5 $\mathrm{min})$ and Ringer's solution $(10 \mathrm{~min})$ for a total of 2 hr. The effects of ACh ( $0.1 \mathrm{~mm}$; Fig. 4 , bottom, $n=3)$ or carbachol (1 $\mu \mathrm{M}$; data not shown) were modest compared with those of membrane depolarization and electric stimulation, presumably because of rapid desensitization of ACh receptors induced by the cholinergic agonists even with the alternate exposure procedure. The effects were blocked by the nicotinic antagonist 

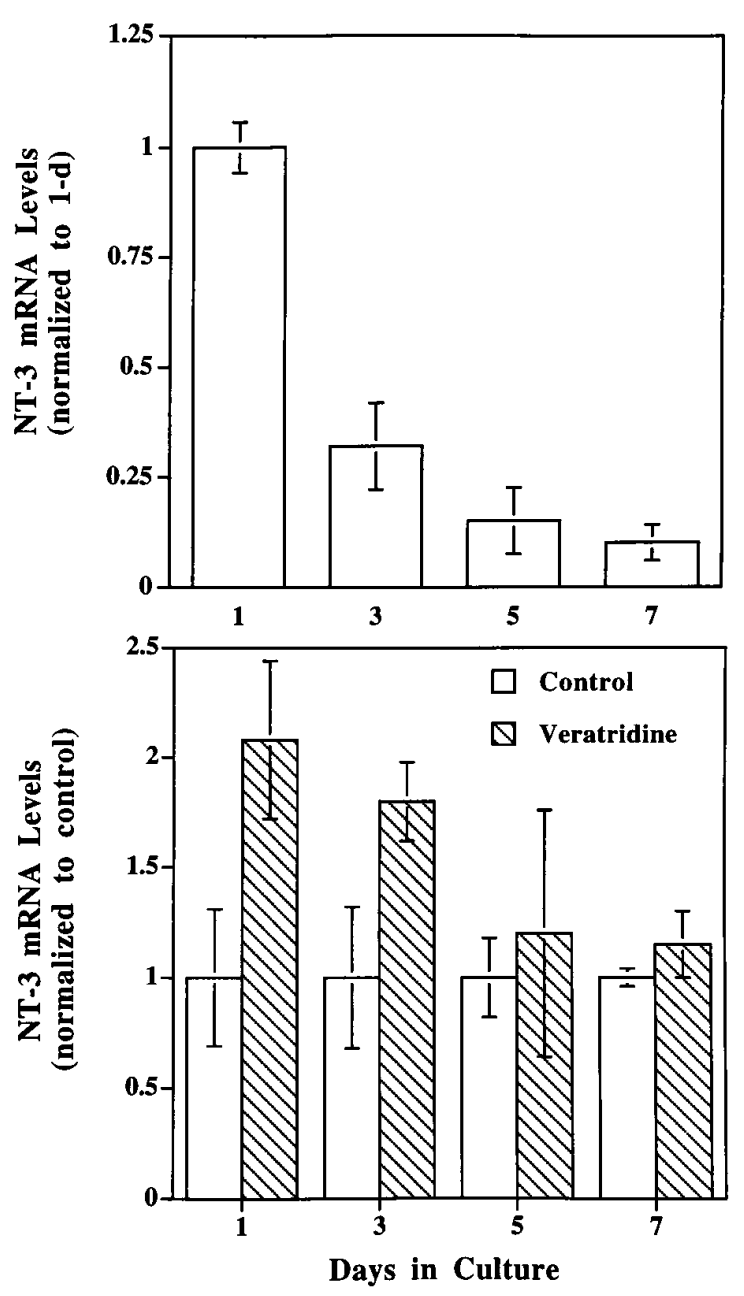

Figure 5. Developmental regulation of NT-3 genes. Top, NT-3 gene expression during development in culture. Muscle cells cultured for different lengths of time, as indicated, were harvested, and the relative levels of NT-3 mRNA were measured (normalized to $1 \mathrm{~d}$ in culture); $n=3$. Bottom, Effects of depolarization on NT-3 gene expression at different developmental stages. The same muscle cultures as above were treated with or without veratridine $(10 \mu \mathrm{M})$ for $2 \mathrm{hr}$, and NT-3 gene expression was determined. Data from veratridine-treated cultures were normalized to their sister control (untreated) cultures for clarity of presentation; $n=3$.

$\alpha$-bungarotoxin $(10 \mu \mathrm{g} / \mathrm{ml})$, whereas $\alpha$-bungarotoxin itself did not affect NT-3 gene expression (Fig. 4, bottom).

\section{Role of $\mathrm{Ca}^{2+}$ influx in NT-3 gene expression}

A direct consequence of membrane depolarization of the muscle cells is an increase in intracellular $\mathrm{Ca}^{2+}$ concentration via $\mathrm{Ca}^{2+}$ influx. Muscle cells cultured for $3 \mathrm{~d}$ exhibited a significant increase in NT-3 mRNA levels after treatment with the $\mathrm{Ca}^{2+}$ ionophores A23187 $(3 \mu \mathrm{M})$ and ionomycin $(3 \mu \mathrm{M})$ for $1 \mathrm{hr}$ (Table 1$)$, suggesting that a rise of intracellular $\mathrm{Ca}^{2+}$ concentration indeed enhanced NT-3 gene expression. The major $\mathrm{Ca}^{2+}$ channel on the skeletal muscle membrane is the L-type $\mathrm{Ca}^{2+}$ channel (Catterall, 1991). Blockade of this channel by dihydropyridine-type agents (nifedipine, nitrendipine, verapamil, etc.) in the same cultures, however, did not prevent the veratridine-induced increase of NT-3 mRNA (Table 1). To test further whether $\mathrm{Ca}^{2+}$ influx is important for NT-3 gene regulation, we used a number of approaches to prevent $\mathrm{Ca}^{2+}$ influx into the cultured muscle cells. Depolarization elicited by veratridine or high concentration of $\mathrm{K}^{+}$ no longer increased NT-3 mRNA in $\mathrm{Ca}^{2+}$-free media (Table 1). The effects of depolarizing agents also were prevented by pretreatment of the muscle cultures with $\mathrm{Cd}^{2+}$, a divalent ion that blocks many types of $\mathrm{Ca}^{2+}$ channels (Table 1 ). These data suggest that $\mathrm{Ca}^{2+}$ influx is involved in activity-dependent NT-3 gene expression.

\section{Developmental regulation of neurotrophin gene expression}

Different neurotrophins may function at different developmental stages. The developmental profile of neurotrophin gene expression was determined in Xenopus muscle cells cultured for various lengths of time. It has been demonstrated that Xenopus muscle cells cultured for $5 \mathrm{~d}$ or longer become much more mature than those for 1-3 d (Cohen, 1980; Kidokoro et al., 1980; Moody and Cohen, 1981, 1982; Peng et al., 1981; Bridgman et al., 1984; Kidokoro and Saito, 1988; Samuels et al., 1990). The levels of NT-3 mRNA decreased with time in culture (Fig. 5, top, $n=3$ ). Interestingly, the depolarization-induced increase of NT-3 gene expression occurred only in immature muscle cells (cultured for 1-3 d), and veratridine was no longer effective in relatively mature myocytes ( 7 d cultures; Fig. 5 , bottom, $n=3$ ). This is consistent with the finding that electric stimulation increased NT-3 mRNA only in muscle cells cultured for $2 \mathrm{~d}$, but not for $6 \mathrm{~d}$ (Fig. 4, top). Thus, the activity-dependent regulation of NT-3 gene expression seems to be restricted to the early stage of development when neuromuscular synapses undergo a maturation process (Wang et al., 1995; Lu et al., 1996).

\section{Potentiation of synaptic activity by muscle-derived factor(s)}

To determine the physiological consequence of activitydependent muscle NT-3 expression on synaptic efficacy, we examined the effects of CM from muscle cultures on functional properties of developing neuromuscular synapses. Immature muscle cells (cultured 2-3 d) were washed thoroughly with Ringer's solution and then treated with veratridine $(10 \mu \mathrm{M})$ in Ringer's solution for $3 \mathrm{hr}$ to enhance NT-3 expression. Then this CM was dialyzed to remove the small molecular weight veratridine but retain protein factors and concentrated to a smaller volume. The concentrated CM was applied to separate 1-d-old nerve-muscle co-cultures. SSCs were recorded from myocytes innervated by single motoneurons in these cultures by whole-cell voltage-clamp recording techniques ( $\mathrm{Lu}$ et al., 1992; Wang et al., 1995). Bath application of CM resulted in a gradual increase of SSC frequency (Fig. 6), similar to that induced by treatment with exogenous NT-3 (Lohof et al., 1993). The increase of SSC frequency occurred rapidly, usually within a period of 5-10 min. There was no change in other properties of the SSC, such as rise time, decay time, and amplitude (Table 2), nor in the distribution of SSC amplitude (data not shown) after treatment with CM. However, the effect of CM did not result from an increase in the rate of action potentials, because these isolated spinal neurons do not fire spontaneous action potentials, and the SSCs recorded from these cultures were TTX-insensitive (Xie and Poo, 1986). Taken together, these results support the idea that CM enhances the presynaptic release of the transmitter ACh at the developing neuromuscular synapses. Several experiments indicated that the presynaptic effect of the $\mathrm{CM}$ was clearly attributable to a factor or factors released from postsynaptic muscle cells. (1) Normal veratridine-treated Ringer's solution not exposed to myocytes and prepared in the same way as $\mathrm{CM}$ had no effect on synaptic activity (data not shown). (2) 


\begin{tabular}{|c|c|c|c|c|c|}
\hline Conditions & & $\begin{array}{l}\text { Rise time } \\
(\mathrm{msec})\end{array}$ & $\begin{array}{l}\text { Decay time } \\
(\mathrm{msec})\end{array}$ & $\begin{array}{l}\text { Amplitude } \\
(\mathrm{pA})\end{array}$ & $\begin{array}{l}\text { Frequency } \\
\text { (events/min) }\end{array}$ \\
\hline \multirow{3}{*}{$\begin{array}{l}\text { Ctr. med. } \\
n=7\end{array}$} & Before & $1.3 \pm 0.2$ & $10.0 \pm 0.9$ & $485 \pm 89$ & $10.0 \pm 0.9$ \\
\hline & After & $1.5 \pm 0.2$ & $11.2 \pm 0.6$ & $458 \pm 74$ & $11.2 \pm 0.6$ \\
\hline & Ratio & $1.13 \pm 0.06$ & $1.14 \pm 0.07$ & $0.98 \pm 0.07$ & $0.9 \pm 0.1$ \\
\hline \multirow{3}{*}{$\begin{array}{l}\text { Cond. med. } \\
n=9\end{array}$} & Before & $1.2 \pm 0.2$ & $9.7 \pm 1.0$ & $518 \pm 64$ & $12.3 \pm 3.9$ \\
\hline & After & $1.4 \pm 0.3$ & $11.1 \pm 1.0$ & $480 \pm 61$ & $31.8 \pm 7.3^{*}$ \\
\hline & Ratio & $1.08 \pm 0.03$ & $1.08 \pm 0.03$ & $0.95 \pm 0.06$ & $3.8 \pm 1.0^{*}$ \\
\hline \multirow{3}{*}{$\begin{array}{l}\text { Cond. med. } \\
+ \text { TrkC-IgG } \\
n=7\end{array}$} & Before & $1.4 \pm 0.2$ & $12.4 \pm 1.2$ & $451 \pm 75$ & $9.6 \pm 1.9$ \\
\hline & After & $1.4 \pm 0.2$ & $11.6 \pm 0.5$ & $429 \pm 82$ & $9.4 \pm 2.2$ \\
\hline & Ratio & $0.99 \pm 0.06$ & $0.97 \pm 0.06$ & $0.94 \pm 0.09$ & $1.0 \pm 0.1$ \\
\hline
\end{tabular}

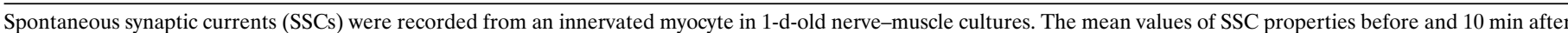

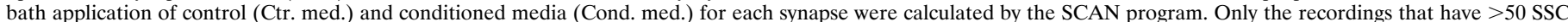

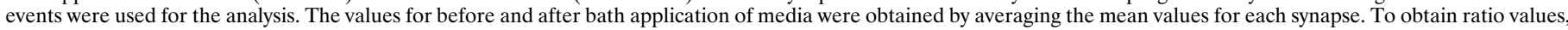

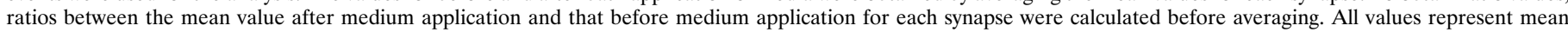
\pm SEM, and $n$ refers to the number of synapses recorded. The data were subject to Student's $t$ test. ${ }^{*} p<0.05$.

Control medium, which was treated identically to CM, except with no depolarization treatment, did not elicit any change in SSCs (Fig. 7). (3) There was no residual veratridine in CM, because its application did not reduce the membrane potential of myocytes or neurons (no change in baseline in Fig. 6).

We next determined whether NT-3 contributed to the effects of $\mathrm{CM}$ on synaptic activity. Western blots that used specific antibodies failed to detect any NT-3 in CM, presumably because the amount of the neurotrophin was below the detection limit. The fusion protein TrkC-IgG, which specifically scavenges NT-3 (Shelton et al., 1995), previously has been shown to block specifically the NT-3 activity in rat (Zheng et al., 1995). Because the amino acid sequences of rat and Xenopus mature NT-3 proteins are very similar, TrkC-IgG should recognize and neutralize the Xenopus NT-3 in the CM. The acute effects of CM were blocked partially by pretreatment of cultures with TrkC-IgG $(1 \mu \mathrm{g} / \mathrm{ml}$; Fig. 7$)$. It is possible that other factors released from depolarized muscle cells also potentiate transmitter secretion at the neuromuscular synapses, because in some cases the potentiating effect of CM cannot be blocked by TrkC-IgG (Fig. 7). Taken together, these results suggest that endogenous NT-3 is at least one of the factors that potentiates synaptic activity during neuromuscular development and that its synthesis is induced by postsynaptic muscle depolarization.

\section{DISCUSSION}

There are two main findings in the present study. First, we have demonstrated the activity-dependent expression of the NT-3 gene in embryonic myocytes. Second, the activity/depolarizationinduced elevation of NT-3 seems to be one of the factors that potentiates synaptic activity at the developing neuromuscular junction, at least in the cell culture model we tested in this study.
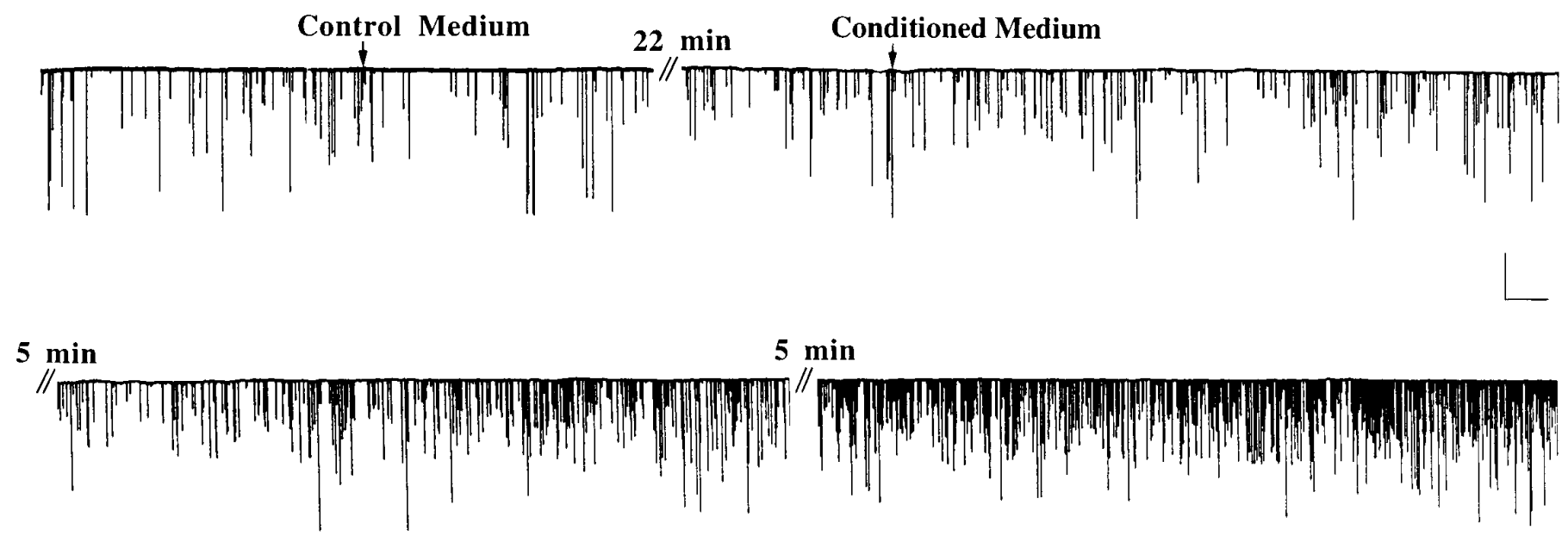

Figure 6. Potentiation of synaptic activity at the developing neuromuscular junction by conditioned medium from depolarized muscle cells cultured for $3 \mathrm{~d}$. A representative recording of spontaneous synaptic currents (SSCs) from an innervated myocyte in a 1-d-old nerve-muscle culture before and after bath application of control and conditioned media is shown. Downward deflections are SSCs $\left(V_{\mathrm{h}}=-70 \mathrm{mV}\right.$, filtered at $\left.150 \mathrm{~Hz}\right)$. Calibration: $250 \mathrm{pA}$, $20 \mathrm{sec}$. Conditioned Medium was the supernatant collected from a muscle culture treated with veratridine (10 $\mu \mathrm{M})$ for $2 \mathrm{hr}$, followed by removal of veratridine via Centricon dialysis. The volume of conditioned medium added to the recording dish was $200 \mu$, which is the equivalent of the supernatant from two muscle cultures. Control Medium was prepared from cultures in the same way as Conditioned Medium except without veratridine treatment. 


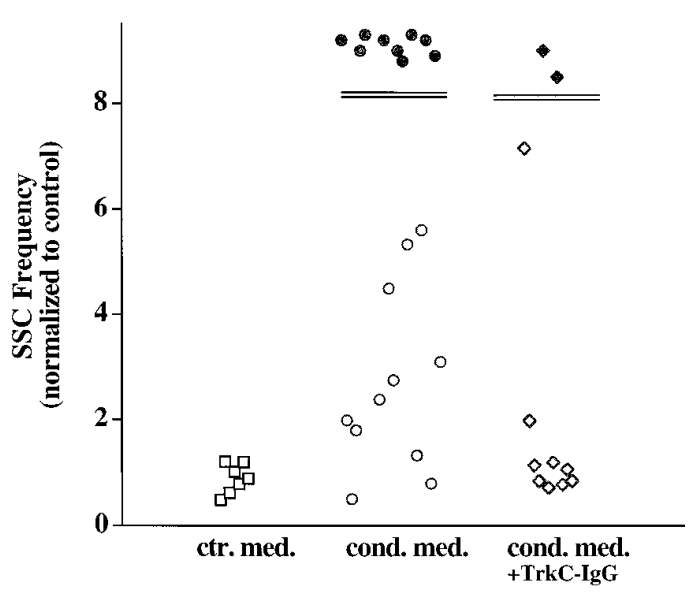

Figure 7. Quantitation of changes in synaptic activity under different experimental conditions. The frequency of SSCs was calculated as the number of SSC events per minute, averaged from at least $10 \mathrm{~min}$ of recording in each condition. Each data point represents one experiment. The ratios of SSC frequencies at $1 \mathrm{~min}$ before and $20 \mathrm{~min}$ after the control medium (ctr. med.) or conditioned medium (cond. med.) are presented. In the cond. med. + TrkC-IgG group, conditioned medium was added to cultures pretreated with TrkC-IgG $(1 \mu \mathrm{g} / \mathrm{ml})$ for $0.5-2 \mathrm{hr}$. The filled circles and filled diamonds represent the ratio of SSC frequency higher than 10.

These results support a positive feedback model: presynaptic activity enhances the postsynaptic expression of NT-3, which in turn potentiates synaptic efficacy (Fig. 8).

It is important to point out that all of our experiments were performed in a cell culture system, which may not reflect the development of the neuromuscular junction in vivo accurately. For example, we do not know whether the pattern of neurotrophin expression as well as the effect of depolarization in different stages observed in the muscle culture correlates precisely with that in various time points in Xenopus development in vivo. Moreover, so far neither acute (Lohof et al., 1993; Stoop and Poo, 1995, 1996) nor long-term (Wang et al., 1995) effects of neurotrophins at the developing neuromuscular synapses in culture have been extended to in vivo. However, several lines of evidence suggest that our present findings are relevant to the neurotrophic regulation of neuromuscular synapse development in vivo. First, the cultured Xenopus muscle cells develop in a very similar manner to those in vivo (see Materials and Methods). Second, the development of neuromuscular synapses in culture also resembles that seen in vivo in many fundamental ways (Kullberg et al., 1977; Cohen, 1980; Myers et al., 1986; Westerfield et al., 1986; Cohen et al., 1987; Buchanan et al., 1989; Evers et al., 1989; Peng et al., 1989, 1991). Third, although no information is available about the muscle expression of neurotrophins in vivo in Xenopus, a great deal about this expression is known in rodents. Developing motoneurons express the neurotrophin receptors TrkB and TrkC (Ernfors et al., 1992; Henderson et al., 1993; Koliatsos et al., 1993; Yan et al., 1993). Different neurotrophins are expressed in muscle cells at different stages of development (Ernfors et al., 1992; Schecterson and Bothwell, 1992; Henderson et al., 1993; Koliatsos et al., 1993; Timmusk et al., 1993; Funakoshi et al., 1995). The levels of BDNF and NT-3 are high in embryonic and neonatal muscle cells but low in those of adult rat, whereas NT-4 has an opposite developmental profile (Funakoshi et al., 1995). These results are consistent with the present study that uses cultured Xenopus embryonic muscle cells. We demonstrated that levels of mRNAs for BDNF and NT-3, but not NT-4, are high in the immature muscle cells, and the expression of NT-3 decreases as the muscle cells mature in culture. Although it is difficult to compare the developmental stages between rodents and Xenopus, these studies point to a general trend of developmental upregulation of NT-4 and downregulation of NT-3. Fourth, similar to Xenopus spinal neurons in culture, the rodent motoneurons are capable of responding to NT-3 early in development in vivo (Sendtner et al., 1992; Henderson et al., 1993; Koliatsos et al., 1993; Wong et al., 1993; Yan et al., 1993). Finally, the muscle expression of NT-4 in adult rodent can be regulated by synaptic transmission and muscle activity (Funakoshi et al., 1995). The present study showed that NT-3 expression in cultured Xenopus developing muscle cells is also activity-dependent. Whether NT-3 expression in developing muscle cells in vivo can be regulated by depolarization remains to be established.

Depolarization is a natural consequence of innervation of muscle cells. We found that upregulation of NT-3 mRNA in cultured muscle cells is directly attributable to muscle depolarization rather than to effects of other factors coreleased with transmitters from the motor nerve terminal. This conclusion is based on the observations that depolarization of the muscle membrane by a variety of means (e.g., the principal neurotransmitter ACh, chemical depolarizing agents, and direct electric stimulation) leads to an enhancement of NT-3 gene expression. Our experiments also indicate that the increase of intracellular $\mathrm{Ca}^{2+}$ concentration via $\mathrm{Ca}^{2+}$ influx may be an intermediate step for activity-dependent NT-3 gene expression. The exact channel type or types that mediate the rise of intracellular $\mathrm{Ca}^{2+}$ and subsequent steps that lead to selective increase in NT-3 mRNA require further investigation.

Whether activity-dependent expression of NT-3 mRNA actually can lead to an increase in the release of NT-3 protein is an issue difficult to address with our experimental system. There was a limited number of cells, and there is no good antibody that can be used to detect Xenopus NT-3 with high affinity.

In the CNS activity-dependent neurotrophin expression seems to be a general phenomenon (Isackson, 1995). However, different responses have been observed for different neurotrophins, suggesting that each neurotrophin gene is regulated independently. In the present study we showed that, although similar levels of BDNF and NT-3 messages were detected, only NT-3 expression was activity-dependent in cultured developing muscle cells (Fig. 2). This selective effect of depolarization suggests that the two neurotrophins may play different roles during neuromuscular development. Interestingly, in all cases in which exogenous application of the two neurotrophins is compared, BDNF exhibited slightly more potent effects on the survival of motoneurons than NT-3 (Sendtner et al., 1992; Koliatsos et al., 1993; Yan et al., 1993). In contrast, exogenous application of NT-3 seems to be more effective than that of BDNF in modulating the properties of neuromuscular synapses. This is true either in acute regulation of transmitter release (Lohof et al., 1993) or in long-term facilitation of synapse maturation (Wang et al., 1995). The functions of the two neurotrophins may overlap during neuromuscular development. It is possible, however, that NT-3 may be involved primarily in the activity-dependent process, such as modulation of synaptic efficacy, whereas BDNF may play a role in other aspects of motoneuron development, such as development of cholinergic phenotypes or cell survival. However, because the BDNF knockout mice did not exhibit a severe loss of motoneuron, the function of BDNF in motoneuron survival has not been firmly established (Ernfors et al., 1994; Jones et al., 1994). 
Figure 8. A schematic model for reciprocal interaction of synaptic activity and NT-3 expression during synapse formation. During neuromuscular development presynaptic activity and consequent depolarization of the postsynaptic myocyte cause a specific increase in the levels of NT-3, which in turn feeds back on presynaptic terminals. Activation of presynaptic TrkC receptors potentiates synaptic transmission and promotes synaptic maturation.

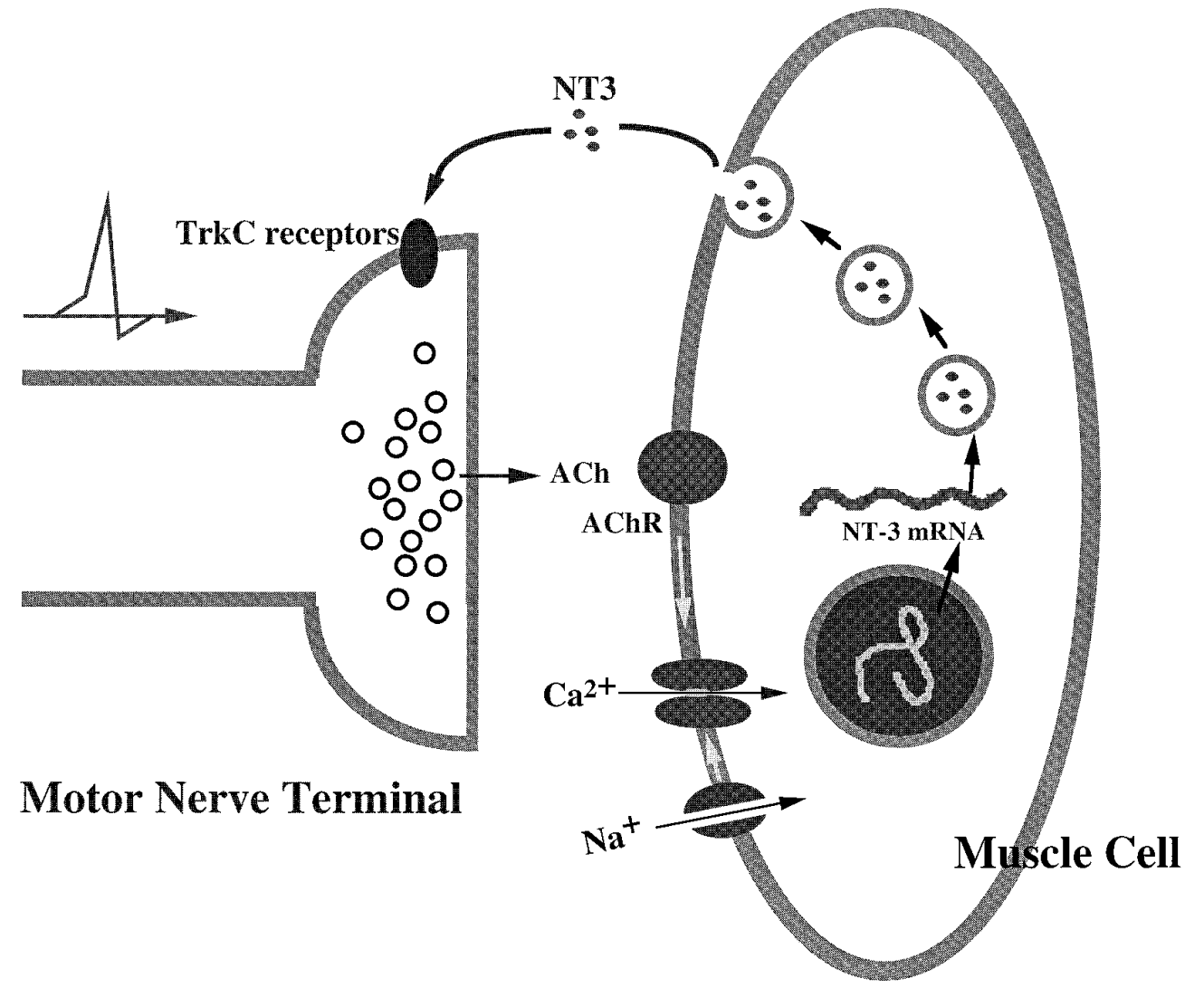

aptic potentiation. During neuromuscular development, innervation and consequent depolarization of muscle cells will specifically increase NT-3 levels. We propose that NT-3 will act in a retrograde manner to potentiate neurotransmission or promote synaptic maturation. Thus, activity-dependent synaptic stabilization could be mediated by NT-3 at the early stage of neuromuscular development.

\section{REFERENCES}

Barbacid M (1993) Nerve growth factor: a tale of two receptors. Oncogene 8:2033-2042.

Barde Y (1989) Trophic factors and neuronal survival. Neuron 2:1525-1534.

Bridgman PC, Nakajima S, Greenberg AS, Nakajima Y (1984) Freezefracture and electrophysiological studies of newly developed acetylcholine receptors in Xenopus embryonic muscle cells. J Cell Biol 98:2160-2173.

Buchanan J, Sun Y, Poo M (1989) Studies of nerve-muscle interactions in cell culture: fine structure of early functional contacts. J Neurosci 9:1540-1554.

Cabelli RJ, Horn A, Shatz CJ (1995) Inhibition of ocular dominance column formation by infusion of NT-4/5 or BDNF. Science 267:1662-1666.

Castren E, Zafra F, Thoenen H, Lindholm D (1992) Light regulates expression of brain-derived neurotrophic factor mRNA in the rat visual cortex. Proc Natl Acad Sci USA 89:9444-9448.

Castren E, Pitkanen M, Sirvio J, Parsadanian A, Lindholm D, Thoenen H, Riekkinen PJ (1993) The induction of LTP increases BDNF and NGF mRNA but decreases NT-3 mRNA in the dentate gyrus. NeuroReport 4:895-898.

Catterall WA (1991) Excitation-contraction coupling in vertebrate skeletal muscle: a tale of two calcium channels. Cell 64:871-874.

Chao MV (1992) Neurotrophin receptors: a window into neuronal differentiation. Neuron 9:583-593.

Cohen MW (1980) Development of an amphibian neuromuscular junction in vivo and in culture. J Exp Biol 89:43-56.

Cohen MW, Rodriguez ME, Wilson EM (1987) Distribution of synaptic trophin gene expression suggests a positive reinforcement mode 
specializations along isolated motor units formed in Xenopus nervemuscle cultures. J Neurosci 7:2849-2861.

Domenici L, Berardi N, Carmignoto G, Vantini G, Maffei L (1991) Nerve growth factor prevents the amblyopic effects of monocular deprivation. Proc Natl Acad Sci USA 88:8811-8815.

Ernfors P, Bengzon J, Kokaia Z, Persson H, Lindvall O (1991) Increased levels of messenger RNAs for neurotrophic factors in the brain during kindling epileptogenesis. Neuron 7:165-176.

Ernfors P, Merlio J, Persson H (1992) Cells expressing mRNA for neurotrophins and their receptors during embryonic rat development. Eur J Neurosci 4:1140-1158.

Ernfors P, Lee K, Jaenisch R (1994) Mice lacking brain-derived neurotrophic factor develop with sensory deficits. Nature 368:147-150.

Evers J, Laser M, Sun Y, Xie Z, Poo M (1989) Studies of nerve-muscle interaction in Xenopus cell culture: analysis of early synaptic currents. J Neurosci 9:1523-1539.

Falls DL, Rosen KM, Corfas G, Lane WS, Fischbach GD (1993) ARIA, a protein that stimulates acetylcholine receptor synthesis, is a member of the Neu ligand family. Cell 72:801-815.

Figurov A, Pozzo ML, Olafsson P, Wang T, Lu B (1996) Regulation of synaptic responses to high-frequency stimulation and LTP by neurotrophins in the hippocampus. Nature 381:706-709.

Frisen J, Verge VMK, Cullheim S, Persson H, Fried K, Middlemas DS, Hunter T, Hokfelt T, Risling M (1992) Increased levels of trkB mRNA and trkB protein-like immunoreactivity in the injured rat and cat spinal cord. Proc Natl Acad Sci USA 89:11282-11286.

Frohman MA (1990) RACE: rapid amplification of cDNA ends. In: PCR protocols, a guide to methods and application (Innis MA, Gelfand DH, Sninsky JJ, White TJ, eds), pp 28-38. San Diego: Academic.

Funakoshi H, Frisen J, Barbany G, Timmusk T, Zachrisson O, Verge VMK, Persson H (1993) Differential expression of mRNAs for neurotrophins and their receptors after axotomy of sciatic nerve. J Cell Biol 123:455-465.

Funakoshi H, Belluardo N, Arenas E, Yamamoto Y, Casabona A, Persson H, Ibanez CF (1995) Muscle-derived neurotrophin-4 as an activitydependent trophic signal for adult motor neurons. Science 268:1495-1499.

Gall CM, Isackson PJ (1989) Limbic seizures increase neuronal production of messenger RNA for nerve growth factor. Science 245:758-761.

Gotz R, Koster R, Winkler C, Raulf F, Lottspeich F, Schartl M, Thoenen H (1994) Neurotrophin-6 is a new member of the nerve growth factor family. Nature 372:266-269.

Hall ZW, Sanes JR (1993) Synaptic structure and development: the neuromuscular junction. Cell [Neuron Review Suppl] 10:99-122.

Hallbook F, Ibanez CF, Persson H (1991) Evolutionary studies of the nerve growth factor family reveal a novel member abundantly expressed in Xenopus ovary. Neuron 6:845-858.

Hamill OP, Marty A, Neher E, Sakmann B, Sigworth FJ (1981) Improved patch-clamp techniques for high-resolution current recording from cell and cell-free membrane patches. Pflügers Arch 391:85-100.

Henderson CE, Camu W, Mettling C, Gouin A, Poulsen K, Karihaloo M, Rullamas J, Evans T, McMahon SB, Armanini MP, Berkemeier L, Phillips HS, Rosenthal A (1993) Neurotrophins promote motor neuron survival and are present in embryonic limb bud. Nature 363:268-270.

Hohn A, Leibrock J, Bailey K, Barde Y (1990) Identification and characterization of a novel member of the nerve growth factor/brain-derived neurotrophic factor family. Nature 344:339-341.

Isackson PJ (1995) Trophic factor response to neuronal stimuli or injury. Curr Opin Neurobiol 5:350-357.

Isackson PJ, Huntsman MM, Murray KD, Gall CM (1991) BDNF mRNA expression is increased in adult rat forebrain after limbic seizures: temporal patterns of induction distinct from NGF. Neuron 6:937-948.

Jo SA, Zhu X, Marchlonnl MA, Burden SJ (1995) Neuregulins are concentrated at nerve-muscle synapses and activate ACh-receptor gene expression. Nature 373:158-161.

Jones KJ, Reichardt LF (1990) Molecular cloning of a human gene that is a member of the nerve growth factor family. Proc Natl Acad Sci USA 87:8060-8064.

Jones KR, Farinas I, Backus C, Reichardt LF (1994) Targeted disruption of the BDNF gene perturbs brain and sensory neuron development but not motor neuron development. Cell 76:989-999.

Kang H, Schuman EM (1995) Long-lasting neurotrophin-induced en- hancement of synaptic transmission in the adult hippocampus. Science 267:1658-1662.

Kidokoro Y, Saito M (1988) Early cross-striation formation in twitching Xenopus myocytes in culture. Proc Natl Acad Sci USA 85:1978-1982.

Kidokoro Y, Yeh E (1982) Initial synaptic transmission at the growth cone in Xenopus nerve-muscle cultures. Proc Natl Acad Sci USA 79:6727-6731.

Kidokoro Y, Anderson MJ, Gruner R (1980) Changes in synaptic potential properties during acetylcholine receptor accumulation and neurospecific interactions in Xenopus nerve-muscle cell culture. Dev Biol 78:464-483.

Kim HG, Wang T, Olafsson P, Lu B (1994) Neurotrophin 3 potentiates neuronal activity and inhibits g-aminobutyrateric synaptic transmission in cortical neurons. Proc Natl Acad Sci USA 91:12341-12345.

Klein R, Smeyne RJ, Wurst W, Long LK, Auerbach BA, Joyner AL, Barbacid M (1993) Targeted disruption of the trkB neurotrophin receptor gene results in nervous system lesions and neonatal death. Cell 75:113-122.

Knipper M, Leung LS, Zhao D, Rylett RJ (1994) Short-term modulation of glutamatergic synapses in adult rat hippocampus by NGF. NeuroReport 5:2433-2436.

Koliatsos VE, Clatterbuck RE, Winslow JW, Cayouette MH, Price DL (1993) Evidence that brain-derived neurotrophic factor is a trophic factor for motor neurons in vivo. Neuron 10:359-367.

Korsching S (1993) The neurotrophic factor concept: a reexamination. J Neurosci 13:2739-2748.

Korte M, Carroll P, Wolf E, Brem G, Thoenen H, Bonhoeffer T (1995) Hippocampal long-term potentiation is impaired in mice lacking brainderived neurotrophic factor. Proc Natl Acad Sci USA 92:8856-8860.

Kullberg RW, Lentz TL, Cohen MW (1977) Development of myotomal neuromuscular junction in Xenopus laevis: an electrophysiological and fine structural study. Dev Biol 60:101-129.

Lessmann V, Gottmann K, Heumann R (1994) BDNF and NT-4/5 enhance glutamatergic synaptic transmission in cultured hippocampal neurones. NeuroReport 6:21-25.

Levine ES, Dreyfus CF, Black IB, Plummer MR (1995) Brain-derived neurotrophic factor rapidly enhances synaptic transmission in hippocampal neurons via postsynaptic tyrosine kinase receptors. Proc Natl Acad Sci USA 92:8074-8077.

Lo DC (1995) Neurotrophic factors and synaptic plasticity. Neuron 15:979-981.

Lohof AM, Ip NY, Poo MM (1993) Potentiation of developing neuromuscular synapses by the neurotrophins NT-3 and BDNF. Nature 363:350-353.

Lu B, Yokoyama M, Dreyfus CF, Black IB (1991) Depolarizing stimuli regulate NGF mRNA expression in cultured hippocampal neurons. Proc Natl Acad Sci USA 88:6289-6292.

Lu B, Greengard P, Poo M (1992) Exogenous synapsin I promotes functional maturation of developing neuromuscular synapses. Neuron 8:521-529.

Lu B, Czernik A, Papov S, Wang T, Poo M, Greengard P (1996) Expression of synapsin I reflects maturation of neuromuscular synapse. Neuroscience 74:1087-1097.

Maffei L, Berardi N, Domenici L, Parisi V, Pizzorusso T (1992) Nerve growth factor (NGF) prevents the shift in ocular dominance distribution of visual cortical neurons in monocularly deprived rats. J Neurosci 12:4651-4662.

Maisonpierre PC, Belluscio L, Squinto S, Ip NY, Furth ME, Lindsay RM, Yancopoulos GD (1990) Neurotrophin-3: a neurotrophic factor related to NGF and BDNF. Science 247:1446-1451.

Maisonpierre PC, Belluscio L, Conover JC, Yancopoulos GD (1992) Gene sequences of chicken BDNF and NT-3. DNA Seq 3:49-54.

McGinnis JF, Stepanik PL, Baehr W, Subbaraya I, Lerious V (1992) Cloning and sequencing of the $23 \mathrm{kDa}$ mouse photoreceptor cellspecific protein. FEBS Lett 302:172-176.

McMahan UJ (1990) The agrin hypothesis. Cold Spring Harb Symp Quant Biol 55:407-418.

Moody CF, Cohen MW (1981) Localization of cholinesterase at sites of high acetylcholine receptor density on embryonic amphibian muscle cells cultured without nerve. J Neurosci 1:596-605.

Moody CF, Cohen MW (1982) Influence of nerve on the formation and survival of acetylcholine receptor and cholinesterase patches on embryonic Xenopus muscle cells in culture. J Neurosci 2:633-646.

Myers PZ, Eisen JS, Westerfield M (1986) Development and axonal 
outgrowth of identified motoneurons in the zebrafish. $\mathrm{J}$ Neurosci 6:2278-2289.

Nieuwkoop P, Faber P 1967) Normal table of Xenopus laevis. Amsterdam: North Holland.

Oppenheim RW (1991) Cell death during development of nervous system. Annu Rev Neurosci 14:453-501.

Oppenheim RW, Yin Q, Prevette D, Yan Q (1992) Brain-derived neurotrophic factor rescues developing avian motoneurons from cell death. Nature 360:755-757.

Patterson S, Grover LM, Schwartzkroin PA, Bothwell M (1992) Neurotrophin expression in rat hippocampal slices: a stimulus paradigm inducing LTP in CA1 evokes increases in BDNF and NT-3 mRNAs. Neuron 9:1081-1088.

Patterson SL, Abel T, Deuel TA, Martin KC, Rose JC, Kandel ER (1996) Recombinant BDNF rescues deficits in basal synaptic transmission and hippocampal LTP in BDNF knockout mice. Neuron 16:1137-1145.

Peng HB, Wolosewick JJ, Cheng PC (1981) The development of myofibrils in cultured muscle cells: a whole-mount and thin-section electron microscopic study. Dev Biol 88:121-136.

Peng HB, Chen QM, de Biasi S, Zhu DL (1989) Development of calcitonin gene-related peptide (CGRP) immunoreactivity in relationship to the formation of neuromuscular junctions in Xenopus myotomal muscle. J Comp Neurol 290:533-543.

Peng HB, Baker LP, Chen Q (1991) Tissue culture of Xenopus neurons and muscle cells as a model for studying synaptic induction. Methods Cell Biol 36:511-526.

Purves D, Lichtman JW (1985) Principle of neural development. Sunderland, MA: Sinauer.

Rao Y (1994) Conversion of a mesodermalizing molecule, the Xenopus brachyury gene, into a neuralizing factor. Genes Dev 8:939-947.

Samuels PL, Riml H, Cohen MW (1990) Formation and survival of a postsynaptic specialization in cultures of embryonic Xenopus nerve and muscle cells. Dev Biol 141:399-411.

Schecterson LC, Bothwell M (1992) Novel roles for neurotrophins are suggested by BDNF and NT-3 mRNA expression in developing neurons. Neuron 9:449-463.

Sendtner M, Holtmann B, Kolbeck R, Thoenen H, Barde Y (1992) Brain-derived neurotrophic factor prevents the death of motoneurons in newborn rats after nerve section. Nature 360:757-759.

Shelton DL, Sutherland J, Gripp J, Camerato T, Armanini MP, Phillips HS, Carroll K, Spencer SD, Levinson AD (1995) Human TRKs: molecular cloning, tissue distribution, and expression of extracellular domain immunoadhesins. J Neurosci 15:477-491.

Stoop R, Poo MM (1995) Potentiation of transmitter release by ciliary neurotrophic factor requires somatic signaling. Science 267:695-699.
Stoop R, Poo MM (1996) Synaptic modulation by neurotrophic factors: differential and synergistic effects of brain-derived neurotrophic factor and ciliary neurotrophic factor. J Neurosci 16:3256-3264.

Sun YA, Poo MM (1987) Evoked release of acetylcholine from the growing embryonic neuron. Proc Natl Acad Sci USA 84:2540-2544.

Tabti N, Poo M (1991) Culturing spinal neurons and muscle cells from Xenopus embryos. In: Culture of nerve cells (Goslin GB, ed), pp 137-153. Boston: MIT.

Thoenen H (1991) The changing scene of neurotrophic factors. Trends Neurosci 14:165-170.

Thoenen H (1995) Neurotrophins and neuronal plasticity. Science 270:593-596.

Timmusk T, Belluardo N, Metsis M, Persson H (1993) Widespread and developmentally regulated expression of neurotrophin-4 mRNA in rat brain and peripheral tissues. Eur J Neurosci 5:605-613.

Wang T, Xie KW, Lu B (1995) Neurotrophins promote maturation of developing neuromuscular synapses. J Neurosci 15:4796-4805.

Westerfield M, McMurray JV, Eisen JS (1986) Identified motoneurons and their innervation of axial muscles in the zebrafish. J Neurosci 6:2267-2277.

Wong V, Arriaga R, Ip NY, Lindsay RM (1993) The neurotrophins BDNF, NT-3, and NT-4/5, but not NGF, upregulate the cholinergic phenotype of developing motor neurons. Eur J Neurosci 5:466-474.

Xie ZP, Poo MM (1986) Initial events in the formation of neuromuscular synapse: rapid induction of acetylcholine release from embryonic neuron. Proc Natl Acad Sci USA 83:7069-7073.

Yan Q, Elliott J, Snider WD (1992) Brain-derived neurotrophic factor rescues spinal motor neurons from axotomy-induced cell death. Nature 360:753-755.

Yan Q, Elliott JL, Matheson C, Sun J, Zhang L, Mu X, Rex KL, Snider WD (1993) Influences of neurotrophins on mammalian motoneurons in vivo. J Neurobiol 24:1555-1577.

Zafra F, Hengerer B, Leibrock J, Thoenen H, Lindholm D (1990) Activity-dependent regulation of BDNF and NGF mRNA in the rat hippocampus is mediated by non-NMDA glutamate receptors. EMBO J 9:3545-3550.

Zafra F, Castren E, Thoenen H, Lindholm D (1991) Interplay between glutamate and g-aminobutyric acid transmitter systems in the physiological regulation of brain-derived neurotrophic factor and nerve growth factor synthesis in hippocampal neurons. Proc Natl Acad Sci USA 88:10037-10041.

Zheng JL, Stewart RR, Gao W (1995) Neurotrophin-4/5 enhances survival of cultured spiral ganglion neurons and protects them from cisplatin neurotoxicity. J Neurosci 15:5079-5087. 